\title{
Paleoseismological investigations on a slow-moving active fault in central Anatolia, Tecer Fault, Sivas
}

\author{
H. Serdar Akyuz ${ }^{1,{ }^{\star}}$, Gulsen Ucarkus ${ }^{2}$, Erhan Altunel ${ }^{3}$, Bulent Dogan ${ }^{2,4}$, Aynur Dikbas ${ }^{1,5}$ \\ ${ }^{1}$ Istanbul Technical University, Faculty of Mines, Department of Geological Engineering, Istanbul, Turkey \\ ${ }^{2}$ Istanbul Technical University, Eurasia Institute of Earth Sciences, Istanbul, Turkey \\ ${ }^{3}$ Eskisehir Osmangazi University, Department of Geological Engineering, Eskisehir, Turkey \\ ${ }^{4}$ Kocaeli University, Department of Geological Engineering, Kocaeli, Turkey \\ ${ }^{5}$ TUBITAK-Marmara Research Center, Earth and Marine Sciences Institute, Gebze-Kocaeli, Turkey
}

\section{Article history}

Received February 11, 2011; accepted November 8, 2011.

Subject classification:

Paleoseismology, Earthquake, Slow-moving fault, Central Anatolia.

\begin{abstract}
Tecer Fault is a $\mathrm{N} 60^{\circ}-70^{\circ} \mathrm{E}$-trending, left-lateral, strike-slip fault to the south of the town of Sivas, Turkey. This fault is considered as the eastward continuation of Deliler Fault, which was classified as a probably active, left-lateral fault on the Active Fault Map of Turkey. We investigated the field characteristics and paleoseismic history of Tecer Fault in detail. After analyzing aerial photographs and satellite images, we mapped the exact fault trace on a 1/25,000 scale topographic map, between the towns of Deliilyas in southwest and Bogazdere in northeast. Tecer Fault is characterized by morphological features such as offset streams and gullies, linear depressions and scarps, and elongated hills. Four paleoseismological trenches were excavated on the northeastern extent of the fault. Two past earthquakes were identified in these trenches, and the dates of the collected charcoal samples suggested that the first of these earthquakes occurred about 8000 B.C. while the more recent event took place around 3500 B.C. Field observations and paleoseismic data indicate that Tecer Fault is an active, pure sinistral, strike-slip fault, and that there is about a 4500 years time span between the two earthquakes. It is also clear that there has not been any surface-ruptured faulting over the last 800 years. Compared with the earthquake characteristics of other strike-slip fault zones in Turkey in terms of time-slip relations, the slip rate can be estimated as about $1 \mathrm{~mm} / \mathrm{yr}$ on Tecer Fault.
\end{abstract}

\section{Introduction}

Central Anatolia has been undergoing deformation through strike-slip fault zones of different trends (Figure 1). Deliler Fault is left-lateral, strike-slip fault that was first mapped as a 'probable active fault' by Saroglu et al. [1992], between the towns of Gemerek in the southwest and Altinyayla in northeast, where a pull-apart basin is forming as a result of left step-over (Figures 2, 3). Tecer Fault is the con- tinuation of Deliler Fault further northeast, with an orientation of $\mathrm{N} 60^{\circ}-70^{\circ} \mathrm{E}$. Although Tecer Fault was named by Aktimur et al. [1990], they did not focus on its geometry and activity. Despite NE-SW-trending, left-lateral, strike-slip faults being mapped in central Anatolia, their existence and activities are under discussion. Saroglu et al. [1992] indicated that Deliler fault is the NE continuation of Erciyes Fault, in central Anatolia. Kocyigit and Beyhan [1998] then proposed a large, active, sinistral intracontinental transcurrent structure, known as the Central Anatolian Fault Zone (CAFZ), which provides a link between the North Anatolian Fault Zone (NAFZ) and the Cyprus Arc. They proposed that the CAFZ has an episodic evolution and is divided into two main parts: the southern part that includes Ecemis Fault and is a paleotectonic structure that reactivated and propagated towards the northeast, forming the northern part that includes Deliler Fault and Tecer Fault. Westaway [1999] did not agree with this idea, and he proposed that most structures are misinterpreted as active faults. Westaway [1999] also objected to the stated seismicity of the zone and the slip rate and total slip. He proposed that the seismic history was incorrect due to the wrong localization of past earthquake epicenters and wrong seismic sources. He stated that no observational evidence was presented for the slip rate, and that the total slip was inadequately documented. Kocyigit and Beyhan [1999] answered these comment of Westaway [1999], insisting on their idea and giving field evidence in different areas along the fault zone. Even though there remain important discussions on the CAFZ, these mostly regard the southern part of the zone (mainly Erciyes Fault and Ecemis Faults). The NE continuation of the zone was sim- 


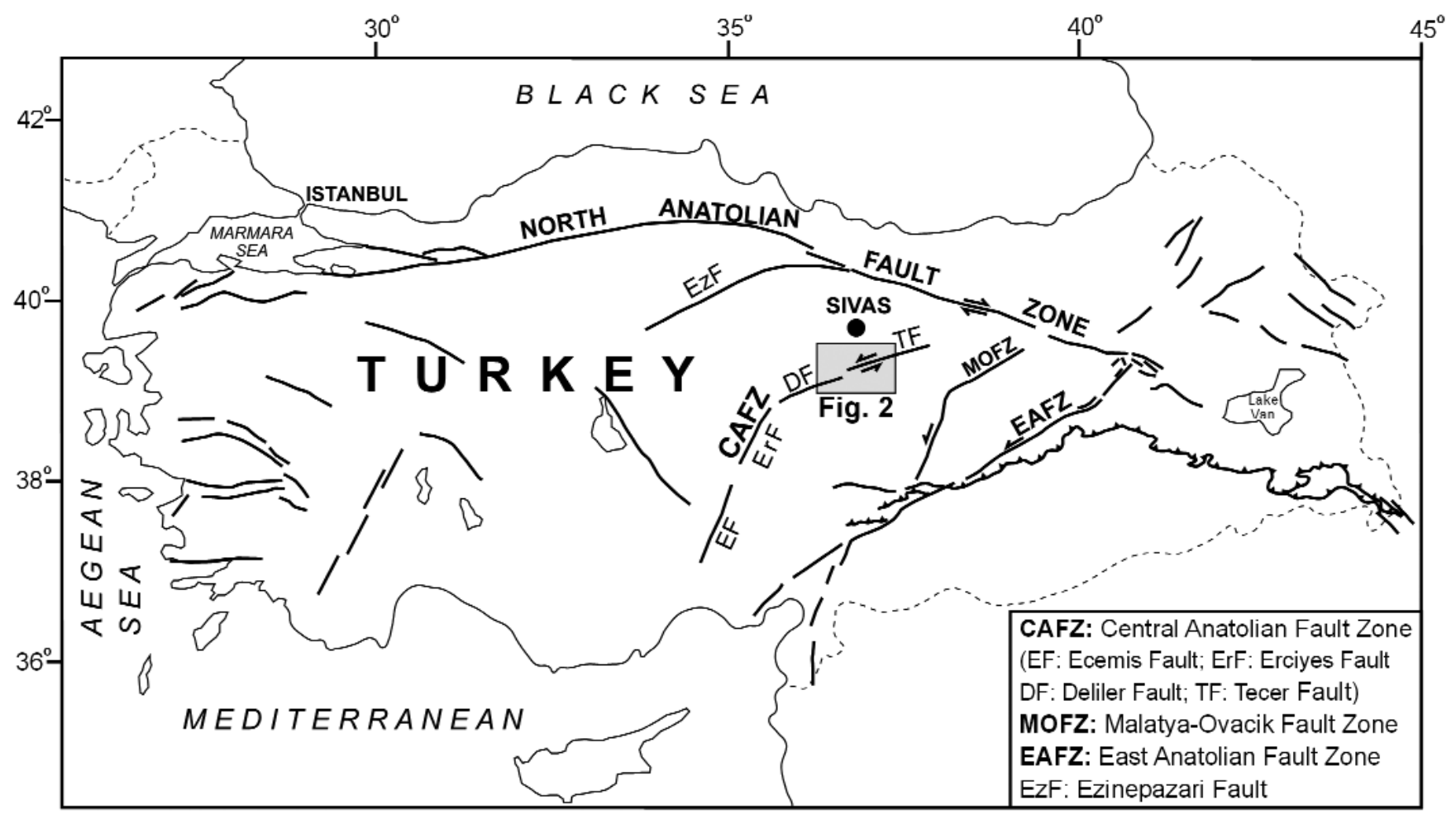

Figure 1. Main active tectonic elements for Turkey [modified from Saroglu et al. 1992], with Tecer Fault (TF) taken from Aktimur et al. [1990] and added to this study. For abbreviations, see key.

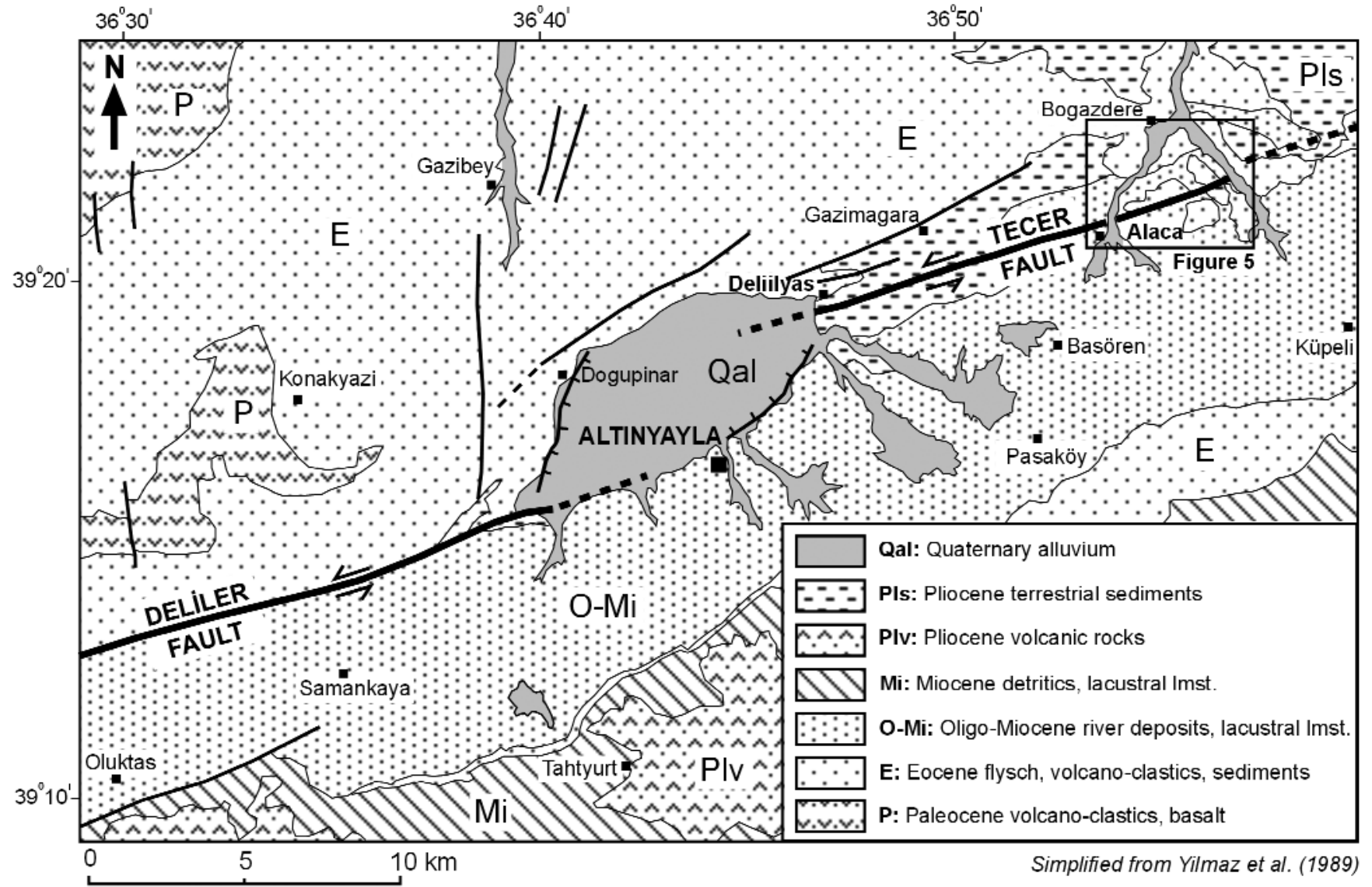

Figure 2. Simplified geological map of the Altinyayla area [modified from Yilmaz et al. 1989].

ply mapped as Deliler Fault first. Kocyigit and Beyhan's [1999] active fault map that included the present study area has lots of fault segments and contains quite complex geo- metric relationships. Tecer Fault, which was also indicated by Kocyigit and Beyhan [1998], is analyzed paleoseismologically for the first time in the present study. Even though Ko- 


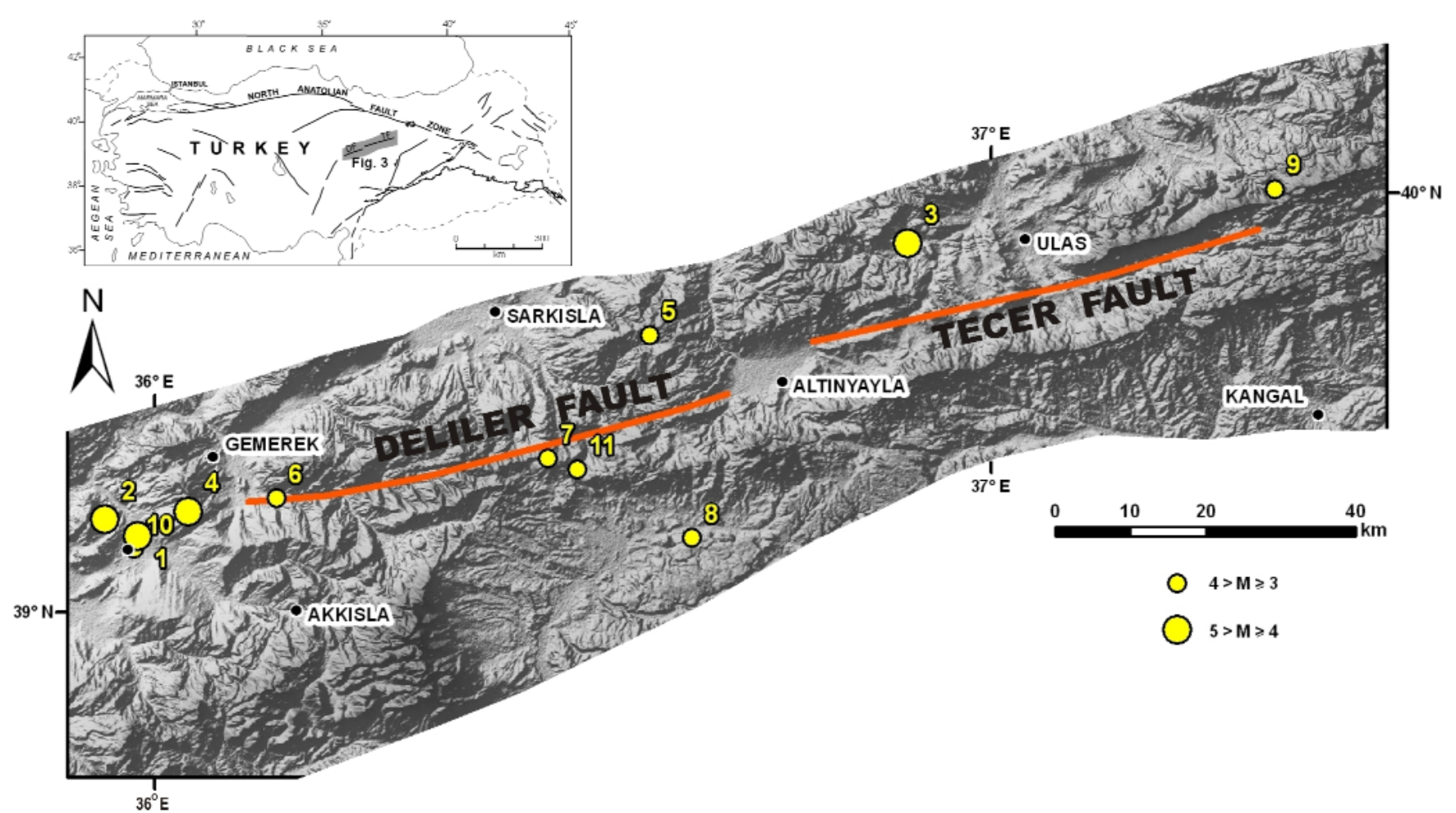

Figure 3. Seismicity around Deliler Fault and Tecer Fault over the last 50 years (Bogaziçi University Kandilli Observatory and Earthquake Research Institute; http://www.koeri.boun.edu.tr/sismo/ default.htm). The numbers correspond to the events listed in Table 1. Inset: location of relief map on Figure 1.

\begin{tabular}{|c|c|c|c|c|c|}
\hline & Date & $\begin{array}{l}\text { Latitude } \\
\left({ }^{\circ} \mathrm{N}\right)\end{array}$ & $\begin{array}{l}\text { Longitude } \\
\quad\left({ }^{\circ} \mathrm{E}\right)\end{array}$ & $\begin{array}{l}\text { Depth } \\
(\mathrm{km})\end{array}$ & Magnitude \\
\hline 1 & $08-31-1960$ & 39.09 & 35.98 & 70 & $4.7(\mathrm{M})$ \\
\hline 2 & 01-23-1985 & 39.11 & 35.94 & 33 & $4.5(\mathrm{M})$ \\
\hline 3 & 07-31-1995 & 39.44 & 36.90 & 22 & $4.1(\mathrm{M})$ \\
\hline 4 & 07-14-2005 & 39.12 & 36.04 & 10 & $4.2\left(\mathrm{M}_{\mathrm{L}}\right)$ \\
\hline 5 & $10-22-2009$ & 39.33 & 36.59 & 3.0 & $3.0\left(\mathrm{M}_{\mathrm{L}}\right)$ \\
\hline 6 & $01-16-2010$ & 39.13 & 36.14 & 5.4 & $3.0\left(\mathrm{M}_{\mathrm{L}}\right)$ \\
\hline 7 & 03-03-2010 & 39.18 & 36.47 & 5.0 & $3.1\left(\mathrm{M}_{\mathrm{L}}\right)$ \\
\hline 8 & $07-12-2010$ & 39.08 & 36.64 & 5.0 & $3.7\left(\mathrm{M}_{\mathrm{L}}\right)$ \\
\hline 9 & 09-18-2010 & 39.50 & 37.33 & 5.0 & $3.3\left(\mathrm{M}_{\mathrm{L}}\right)$ \\
\hline 10 & $11-28-2010$ & 39.07 & 35.97 & 5.0 & $3.1\left(\mathrm{M}_{\mathrm{L}}\right)$ \\
\hline 11 & $01-15-2011$ & 39.17 & 36.50 & 11.7 & $3.0\left(\mathrm{M}_{\mathrm{L}}\right)$ \\
\hline
\end{tabular}

Table 1. Instrumental seismicity around Deliler Fault and Tecer Fault over the last 50 years [Kalafat et al. 2008]. These events are also plotted in Figure 3.

cyigit and Beyhan [1998] indicated some seismicity around Tecer Fault, the precision of these data is suspect due to the poor seismic network in the past and the small to moderate magnitude earthquakes. The combination of high resolution images of the study area, field observations, and paleoseismological data has indicated that Tecer Fault is an active fault. Additional field evidence would make a significant contribution to the understanding of the nature of the present deformation in the upper crust in central Anatolia. The present study presents field evidence and paleoseismological data for the activity and kinematic characteristics of Tecer Fault, which is a poorly known fault to the south of the town of Sivas in central Anatolia (Figures 1, 2).

Our observations were conducted on the western part of the approximately $45-\mathrm{km}$-long Tecer Fault. The fault geometry was first analyzed using aerial photographs and satellite images. Following this stage, the faults were mapped in the field on a $1 / 25,000$ scale topographic map. Paleoseismological trench studies were conducted in the AlacaBogazdere area (Figure 2). We believe that the data provided 
here on the seismic history of Tecer Fault will help in our understanding of both the neotectonic framework of Turkey and the seismic risk of the area.

\section{Tectonic setting}

The central Anatolian block has been squeezed in the east between the Arabian plateau and the Eastern Anatolian block, and it is moving westwards along the North and East Anatolian Faults [Sengor 1980]. As a result of the westward movement, the tectonic structures are accommodated in different directions in central Anatolia. The tectonic structures to the south of Sivas are mainly NE-SW-trending, left-lateral, strike-slip faults (Figure 1), which include Deliler Fault and Tecer Fault. Aktimur et al. [1990] mapped Tecer Fault as a neotectonic structure, although they did not follow it up to the Altinyayla pull-apart basin. According to Saroglu et al. [1992], Deliler Fault terminates around Altinyayla, and they did not map any fault north and further northeast of the Altinyayla Basin. Gursoy et al. [1997] proposed an anticlockwise rotation between the North Anatolian Fault Zone and East Anatolian Fault Zone through paleomagnetic studies, and they suggested that Deliler Fault was formed as a result of this rotation. Kocyigit and Beyhan [1998] mapped Deliler Fault and Tecer Fault to within the CAFZ. Conversely, Westaway [2003] proposed that there are no active faults in this part of Anatolia, except for Ecemis Fault.

The main geological units around the Altinyayla Basin are the sedimentary and volcanic rock of the Paleocene to Miocene ages, Pliocene terrestrial sediments, and volcanic cover (Figure 2) [Y1lmaz et al. 1989], and Holocene alluvialfluvial young sediments and basin-fill deposits.

Investigation of the instrumental earthquake records shows that only a few small earthquakes have occurred along Deliler Fault and Tecer Fault in the last 50 years. These were shallow earthquakes, between $3 \mathrm{~km}$ and $33 \mathrm{~km}$ in depth, and the maximum magnitude was M 4.7 (August 31, 1960), which occurred on the western part of Deliler Fault, and M 4.1 (July 31, 1995) on Tecer Fault. (Table 1; Figure 3). No large historical earthquakes have been recorded in this part of Anatolia over the last 2000 years [e.g. Ergin et al. 1967, Tan et al. 2008, Guidoboni et al. 1994, Guidoboni and Comastri 2005, Ambraseys 2010].
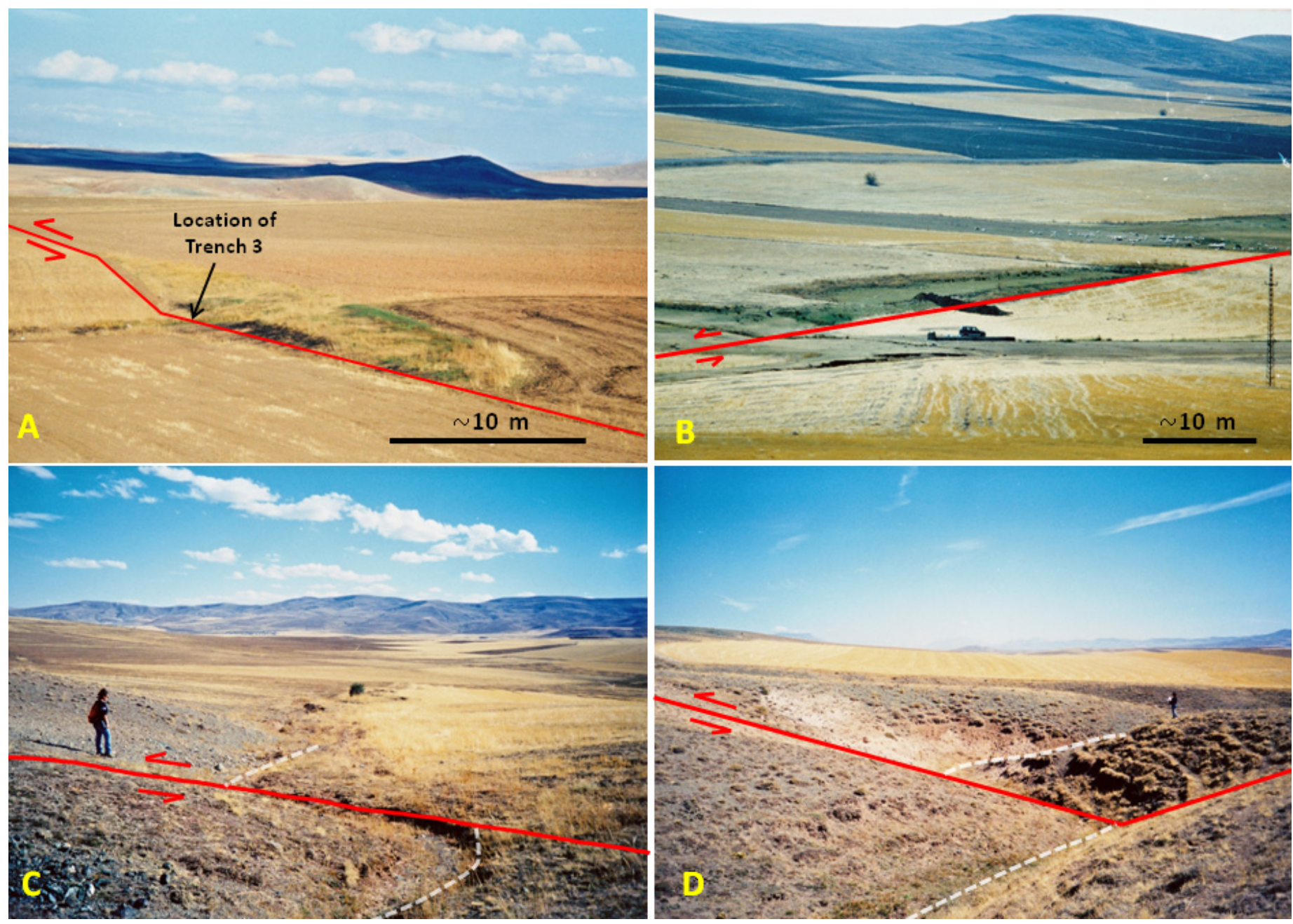

Figure 4. Morphological indicators of Tecer Fault. A. Linear scarp to the south of Bogazdere (looking to the SE, towards the site of Trench-3). B. Linear depression to the west of Alaca (looking to the NE). C. Offset $(6 \pm 0.5 \mathrm{~m}$ ) of stream to the north of Alaca (looking to the NW). D. Offset (12 $\pm 1 \mathrm{~m}$ ) of stream to the NW of Alaca (looking to the NW). Dashed white lines represent the approximate bases of the gullies. Geologist in (C) and (D) for scale (1.75 $\mathrm{m}$ tall). 


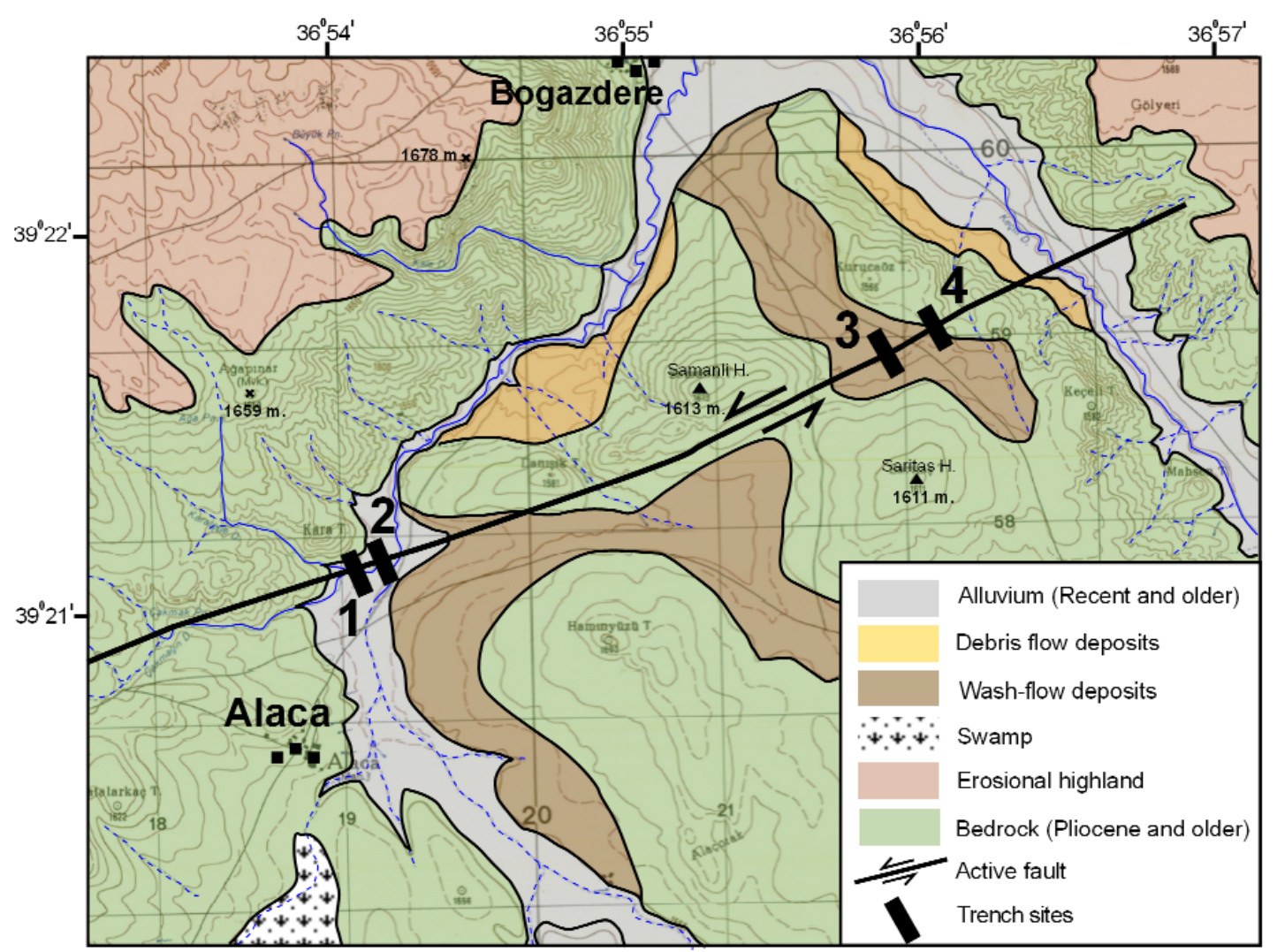

Figure 5. Geomorphological map of the investigation area. See key for details.

\section{Paleoseismological studies}

The exact location of an active fault is of vital importance for paleoseismological trench studies. Thus, to map the fault trace in the study area, the morphological features were carefully investigated. Detailed investigations showed that linear scarps (Figure 4a), NE-SW-trending depressions (Figure $4 \mathrm{~b}$ ), offset streams (Figure $4 \mathrm{c}, \mathrm{d}$ ) and NE-SW-extending wet-dry contact and tonal lineament are aligned along a NESW trending line. Offset streams clearly indicate left-lateral motion, and $6 \mathrm{~m}$ to $30 \mathrm{~m}$ sinistral offsets were measured around the Alaca-Bogazdere area. Up to $30 \mathrm{~m}$ cumulative offset implies that faulting during previous earthquakes occurred along the same fault splay or fault structure. A detailed geomorphological map was made to select for convenient trench locations (Figure 5). The well-bedded detritic rock, marl with serpentinite and limestone blocks, and terrestrial sediments constitute the basement rock in the area (Figures 2, 5). These are covered by Holocene to Recent detritic sediments unconformable along both of the sides of active streams and slopes of hills (Figure 5). The study area has moderate relief between altitudes of $1500 \mathrm{~m}$ and $1700 \mathrm{~m}$ a.s.l. The area is generally erosional in the higher elevation, and depositional in the relatively lower parts. Fluvial, swamp and slope deposits blanket the basement units. Alhough there is no clear offset on lithological boundaries, successive hills, such as those of Danisik, Samanli and Kurucaoz on the northern part of the fault, represent morphological indicators of an active fault trace around study area (Figure 5).
Four trenches were excavated on the fault trace, and logged (Figure 5). Trench sites 1 and 2 were chosen on an alluvial plane, while trench sites 3 and 4 were on wash-flow deposits. Due to ongoing recent sedimentation and slow block movement, no visible offsets are seen on the young formation boundaries. The linear humidity and related relative darkness difference on the ground provides a clue to the location of the fault trace for the trench-1 and trench- 2 sites. The trench-3 site has a visible linear escarpment on a slightly inclined ground surface of recent wash-flow deposits. Trench4 was chosen on a morphological neck on the fault trace. Charcoal samples in trench walls were collected for ${ }^{14} \mathrm{C}$ (radiocarbon) dating and analyzed in the Arizona University AMS laboratory, Arizona, USA. All of these 14C analyses were calibrated using OxCal, version 4.1.7 [Bronk Ramsey 2009], in which the atmospheric correction curves of Reimer et al. [2009] were been taken into account (Table 2).

\subsection{Trench-1}

There is a ca. 50-m-long and 10-m-wide, ENE-WSWtrending depression in this location (Figure $4 \mathrm{~b}$ ). Towards the northeast of this depression, there is a $\mathrm{N} 65^{\circ} \mathrm{E}$-trending tonal lineament on the plain ground, and Trench-1 was excavated across this linear line. The trench was $15 \mathrm{~m}$ in length and 2.5 $\mathrm{m}$ in depth. Clay, silt and fine sand layers of fluvial sediments were identified on the trench wall and logged (Figures 6, 7). Yellowish fine sand at the lowermost part of the northern half of the trench ws cut by a $45^{\circ}$ to $50^{\circ} \mathrm{SE}$ dipping contact. 


\begin{tabular}{|c|c|c|c|c|c|c|c|c|c|c|}
\hline $\begin{array}{l}\text { Sample } \\
\text { ID }\end{array}$ & $\begin{array}{c}\mathrm{C} \\
\text { yield }\end{array}$ & $\begin{array}{c}\mathrm{C} \\
\text { mass }\end{array}$ & $\begin{array}{c}\text { Sample } \\
\text { type }\end{array}$ & $d^{13} \mathrm{C}$ & $\begin{array}{c}\mathbf{F} \\
\left(\mathbf{d}^{13} \mathbf{C}\right)\end{array}$ & $\begin{array}{c} \pm \mathrm{dF} \\
\left(\mathrm{d}^{13} \mathrm{C}\right)\end{array}$ & $\begin{array}{c}{ }^{14} \mathrm{C} \text { age } \\
\mathrm{BP}\end{array}$ & $\begin{array}{l} \pm^{14} \mathrm{C} \\
\text { age }\end{array}$ & $\begin{array}{l}\text { Calibrated } \\
\text { Dates }\end{array}$ & $\begin{array}{l}\text { Probability } \\
0.95(2 \sigma \%)\end{array}$ \\
\hline $\mathrm{T} 1-\mathrm{C} 1$ & 0.1 & 0.38 & Charcoal & -26.3 & 0.5523 & 0.0038 & 4769 & 56 & $\begin{array}{l}3652 \mathrm{BC}-3496 \mathrm{BC} \\
3460 \mathrm{BC}-3376 \mathrm{BC}\end{array}$ & 75.320 .1 \\
\hline $\mathrm{T} 2-\mathrm{C} 1$ & 0.64 & 1.37 & Charcoal & -14.1 & 0.3306 & 0.0022 & 8891 & 52 & $\begin{array}{l}\text { 8243BC-7935BC } \\
\text { 7929BC-7911BC } \\
\text { 7901BC-7831BC }\end{array}$ & 87.81 .56 .1 \\
\hline $\mathrm{T} 2-\mathrm{C} 2$ & 0.1 & 0.41 & Charcoal & -24.8 & 0.5454 & 0.0036 & 4870 & 53 & $\begin{array}{l}3776 \mathrm{BC}-3626 \mathrm{BC} \\
3597 \mathrm{BC}-3526 \mathrm{BC}\end{array}$ & 78.616 .8 \\
\hline T2-C3 & 0.1 & 0.4 & Charcoal & -22.9 & 0.5602 & 0.0037 & 4654 & 54 & $\begin{array}{l}3632 \mathrm{BC}-3560 \mathrm{BC} \\
3537 \mathrm{BC}-3344 \mathrm{BC}\end{array}$ & 10.784 .7 \\
\hline T3-C1 & 0.03 & 0.06 & Charcoal & -24.6 & 0.162 & 0.014 & 8610 & 68 & 7816BC-7527BC & 95.4 \\
\hline T4-S1 & 0.2 & 0.75 & $\begin{array}{c}\text { Charcoal/ } \\
\text { soil }\end{array}$ & -22.5 & 0.9014 & 0.004 & 834 & 36 & $\begin{array}{l}\text { 1055AD-1077AD } \\
1154 \mathrm{AD}-1270 \mathrm{AD}\end{array}$ & 3.392 .1 \\
\hline
\end{tabular}

Table 2. Measured and calibrated radiocarbon ages from the collected samples. The measurements were calibrated using OxCal, version 4.1.7 [Bronk Ramsey 2009], in which the atmospheric correction curves are those of Reimer et al. [2009].

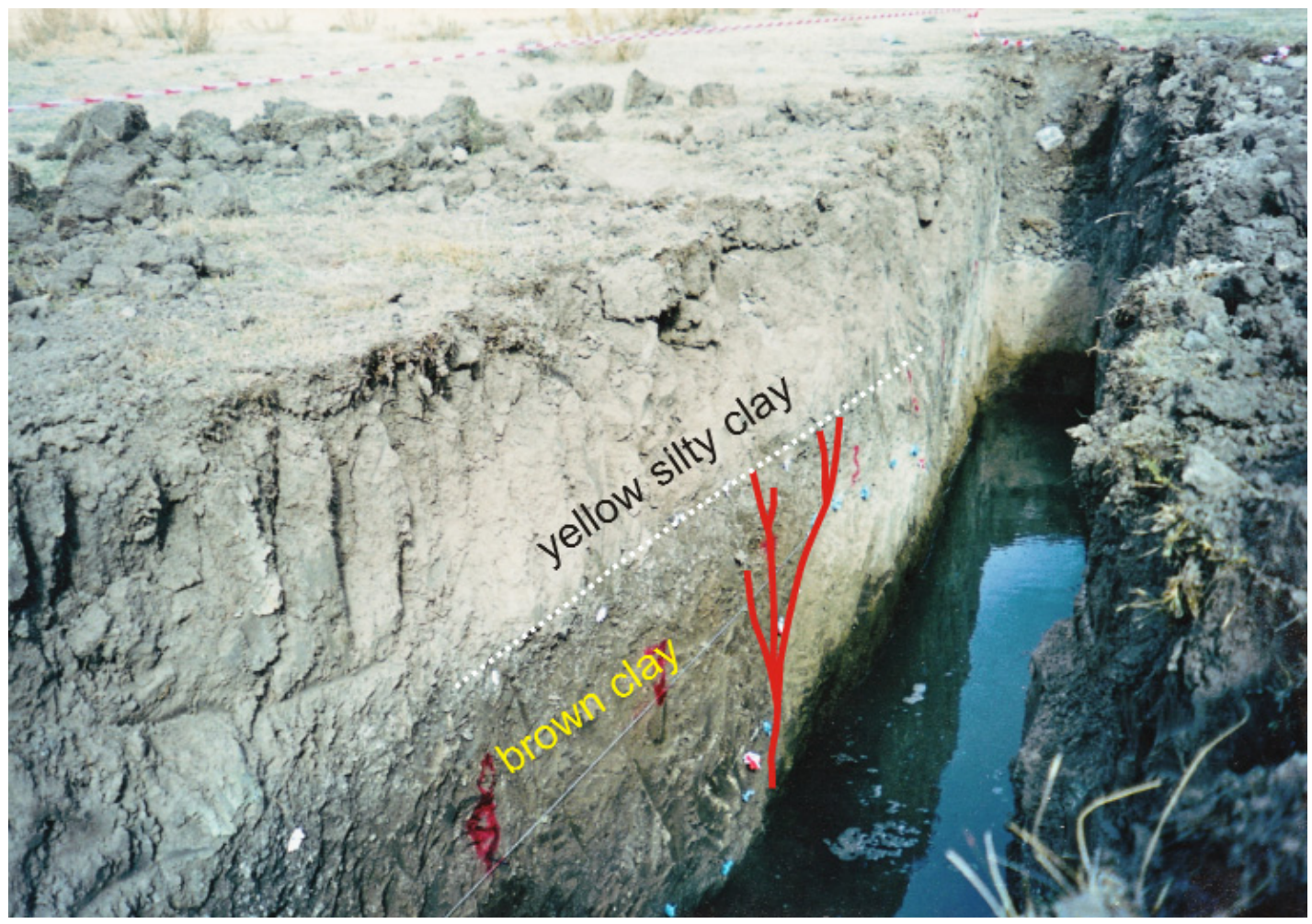

Figure 6 (left). General view of Trench-1 (looking to the north). Color difference between the two sides of the fault is clearly seen. Dashed white line, base of event horizon.
Figure 7 (below). Log of Trench-1, western wall.

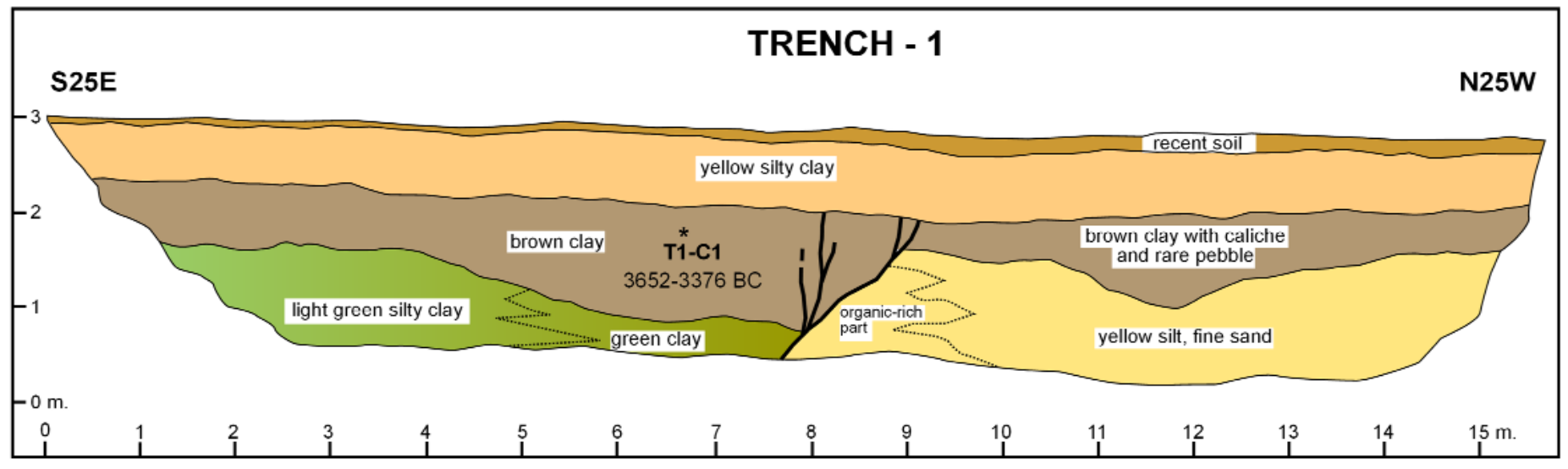




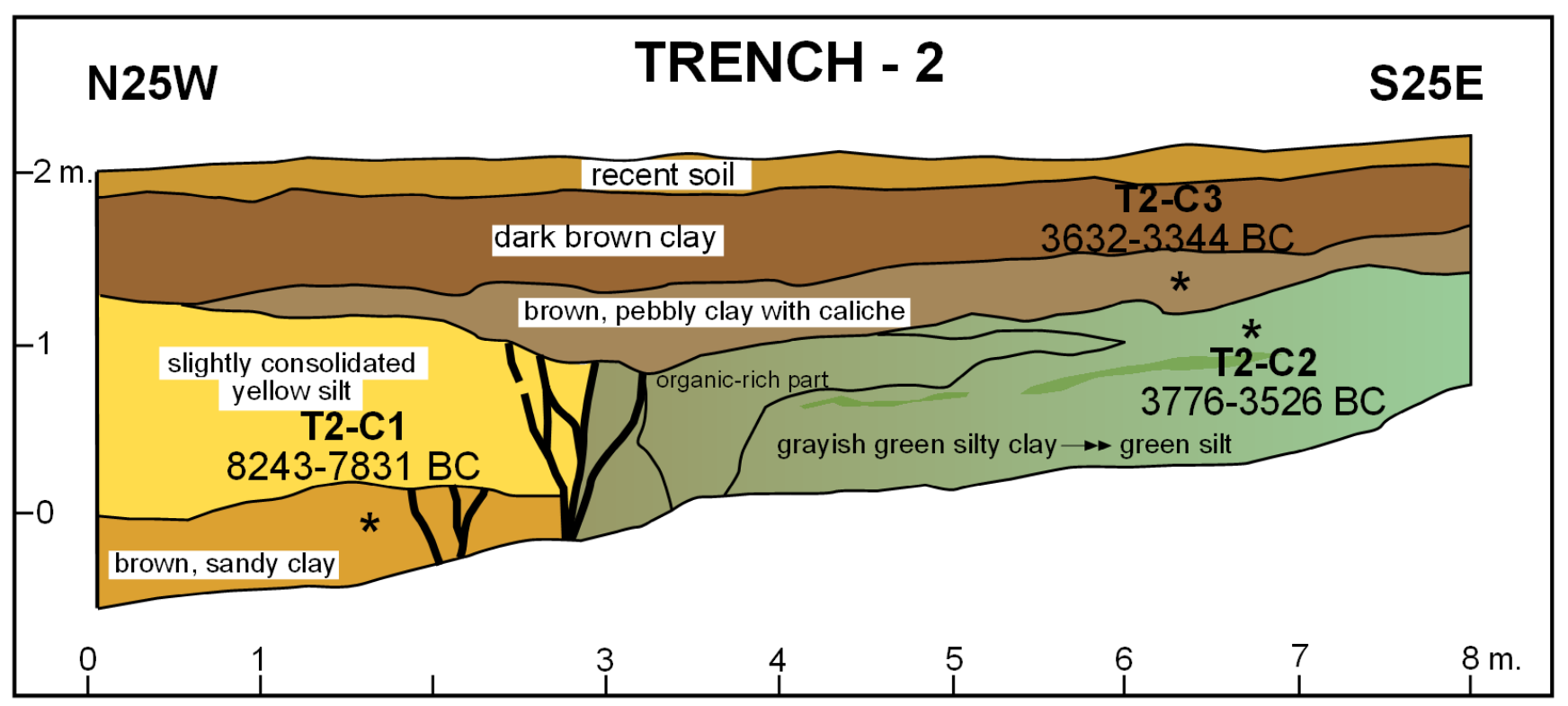

Figure 8. Log of Trench-2, eastern wall.

At the bottom part of the trench at the southern end, there was green silty clay. A brown clay level covered both units. A fault zone cut these levels at around the 8th meter, and caused more than a 1-m vertical separation in the brown clay (Figure 7). A yellowish silty clay level unconformably covers this structure horizontally. Considering that the fault line was straight and that the lithological units were horizontal, the more than 1-m offset in the brown clay is probably the cumulative vertical separation, which suggests multiple events along the same rupture zone. High underground water did not allow us to investigate the deeper parts of this fault-related structure (Figure 6). A charcoal sample from the upper part of the offset brown clay (sample T1-C1) yielded a date of ca. 3500 B.C. and ca. 3400 B.C. with $75 \%$ and $20 \%$ probability, respectively (Table 2). The date of this stratum implies that an earthquake should have occurred after this date.

\subsection{Trench-2}

This second trench was located ca. $50 \mathrm{~m}$ east of Trench1. It was $8 \mathrm{~m}$ in length and $2.5 \mathrm{~m}$ in depth. Similar finegrained unconsolidated sediments and clear discontinuities were observed on the trench wall (Figure 8). The trench wall provided clear evidence for at least two past earthquakes. Sub-parallel and branched faults cut the brown sandy clay at the 2nd meter, but they were covered by yellow silt, which is clear evidence for a past earthquake. At the 3rd meter, there was vertical contact between the green silty clay to the south and the brown sandy clay and slightly consolidated yellow silt to the north. Detailed examination showed that the contact represents a fault zone that was blanketed by brown, pebbly clay. This stratigraphic relationship is an indication of a different earthquake that was more recent than the previous one. A charcoal sample from the brown, sandy clay (T2C1) gave a more recent limit than the older event, yielding an age of ca. 8000 B.C. (Table 2). Two charcoal samples were collected to bracket the more recent event (Figure 8, T2-C2, T2-C3). The lower sample from the green silt (T2-C2) gave an age of ca. 3600 B.C., while the upper sample from the covering unit of brown, pebbly clay (T2-C3) yielded an age of ca. 3400 B.C. (Table 2). These dates support the lower and upper limits for the more recent earthquake in this trench.

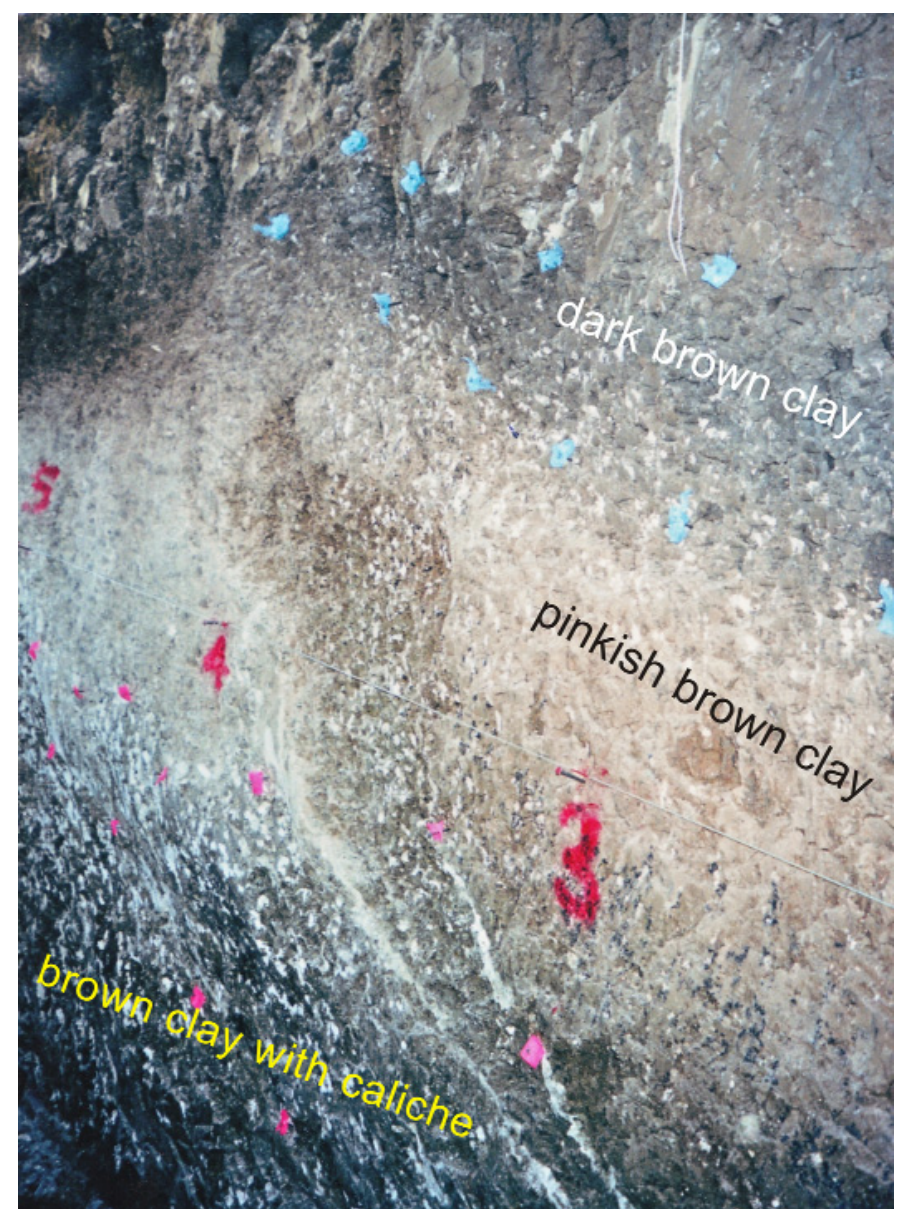

Figure 9. General view of Trench-3. Note that caliche fills make the sliding surfaces more clear. 


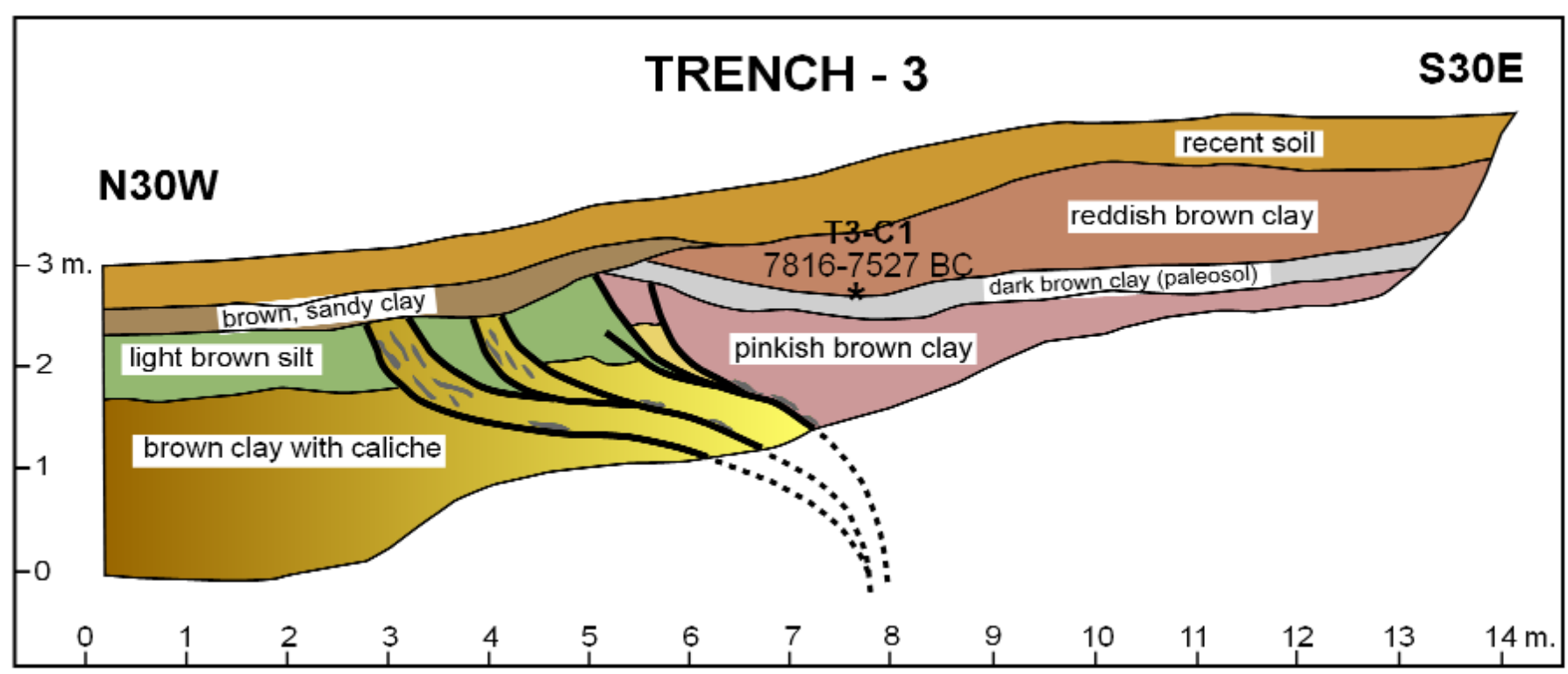

Figure 10. Log of Trench-3, eastern wall.

\subsection{Trench-3}

This third trench was excavated on a wet-dry field boundary on the northern part of Saritas Hill (Figure 5). The trench was perpendicular to the lineament, which was

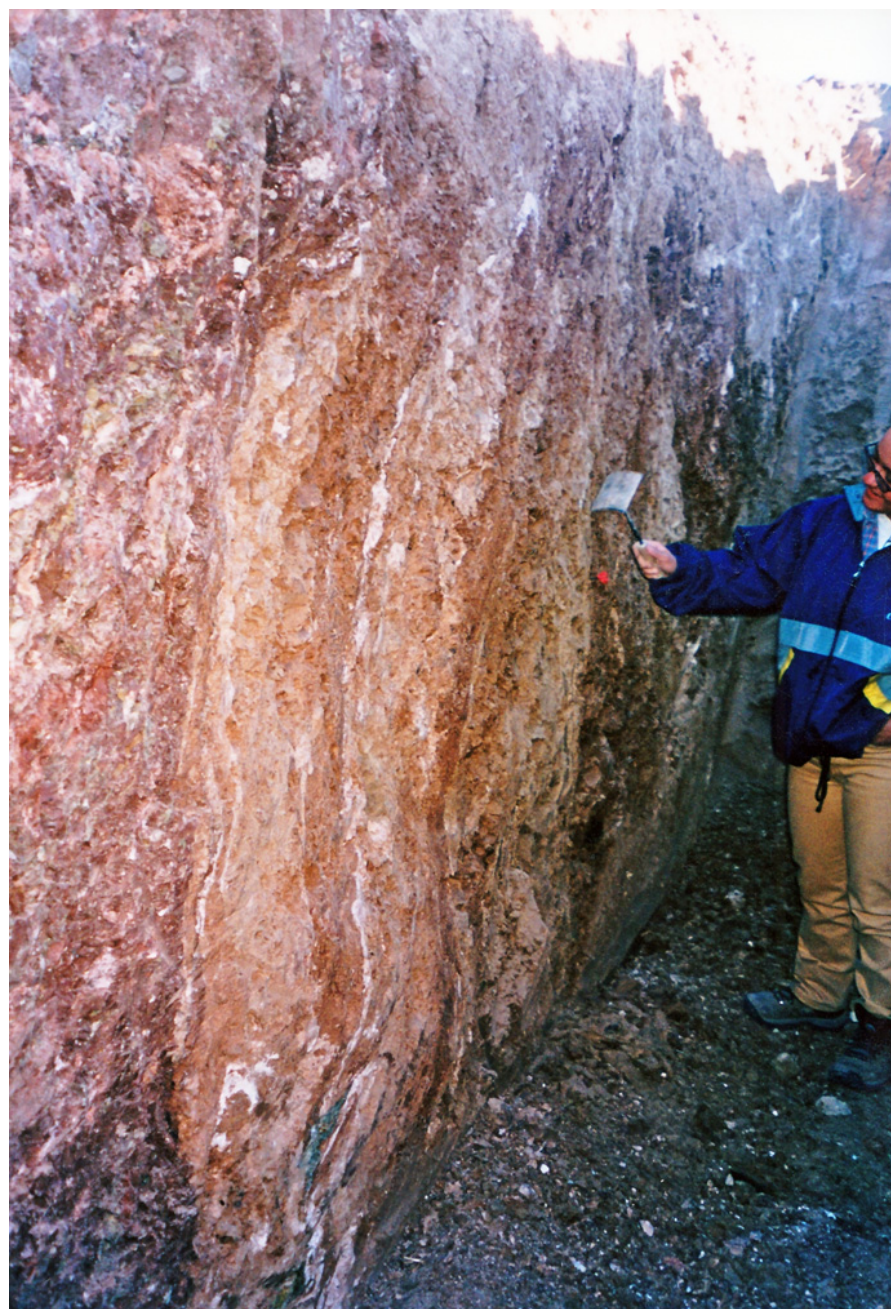

Figure 11. General view of Trench-4. Strongly sheared units and vertical sliding surfaces are seen clearly. clearly represented by a maximum 1-m-high scarp, for a distance of at least $100 \mathrm{~m}$ (Figure 4A). The length of the trench was $14 \mathrm{~m}$ and the depth was ca. $3 \mathrm{~m}$. Fine-grained unconsolidated sediments were exposed in the trench walls. Different clay and silt levels and some discontinuity structures were defined (Figures 9, 10). The units were nearly horizontal near both the northern and southern ends of the trench, although a deformed zone was identified between the $3 \mathrm{rd}$ and 7 th meters. Several striated surfaces were noted within this deformed zone. The striated surfaces dipped steeply southwards $\left(80^{\circ}\right)$ at the top, but the dips became more gentle (nearly horizontal) at the bottom of the trench. It was not possible to excavate deeper to see the structure further downwards because of the high underground water level. These surfaces were partly filled by caliches, which made the sliding surfaces clear. Horizontal slickensides were also observed on small fault surfaces. This deformed zone was interpreted as the near surface reflection of the main fault at depth. A ca. $25-\mathrm{cm}$-thick paleosol covered these structures at the southern half of the trench. A charcoal sample from just above the thin (ca. 20$\mathrm{cm}$ ) paleosol (T3-C1) was dated, and it yielded for the lower part of reddish brown clay an age of ca. 7700 B.C., with $95 \%$ probability (Table 2). This date gives another upper limit for the older surface-rupturing event.

\subsection{Trench-4}

Trench-4 was located ca. $800 \mathrm{~m}$ east of Trench-3 (Figure 5). It was opened between Eocene rock and Pliocene sediment, on a small hill. These units were blanketed by recent deposits. The length of the trench was $8 \mathrm{~m}$ and the depth was $2.5 \mathrm{~m}$. The northern $2 \mathrm{~m}$ of the trench was bedrock (Eocene sediment), while the southern part was consolidated reddish sandy clay and pebbly clay of the Pliocene, with different sized bedrock blocks. Both the Eocene and the Pliocene units in the trench were strongly sheared (Figure 11). Several ver- 


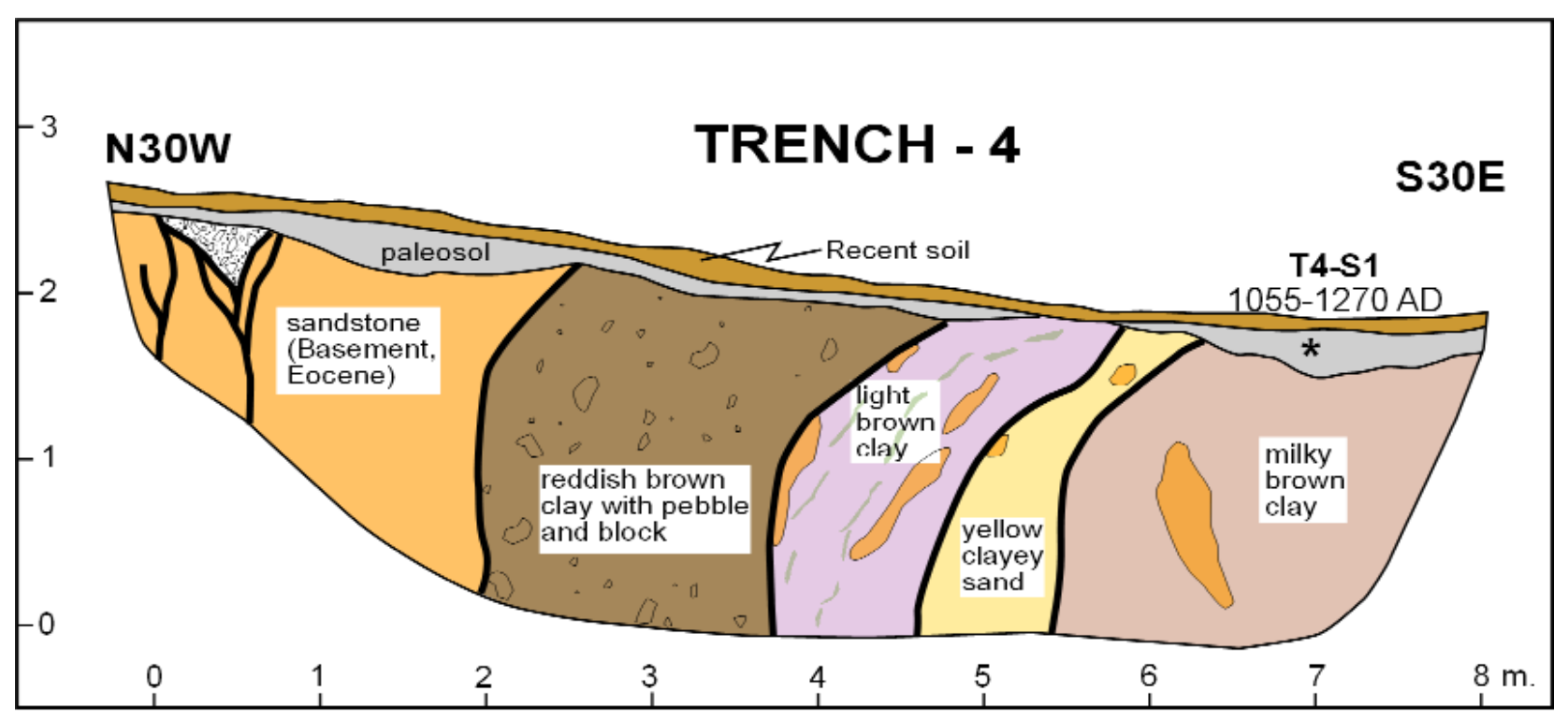

Figure 12. Log of Trench-4, eastern wall.

tical discontinuity surfaces were clearly identified on the trench wall (Figure 12). All of the faults had a similar orientation, between $\mathrm{N} 60^{\circ}-70^{\circ} \mathrm{E}$. These reached to the upper part of the trench, and were covered by paleosol. It was difficult to determine the main fault, because all of these structures reached the surface, although the large vertical separation between the fault branches suggests that this zone was formed during multiple events. These branches and the general blocky chaotic structures are interpreted as a large sinistral shear zone along the trench. There was a wedgeshape infill in the Eocene basement near the northern end of the trench. Although such an infill in fault zones represents an old event in paleoseismological studies [e.g. McCalpin 1996], it is difficult to attribute this to a certain event without dating. Sample T4-S1 from paleosol that covered the infill and the other fault branches gave a time span of 1055 A.D. to 1270 A.D. (Table 2) for the formation of the paleosol, which suggests that the fault zone has not been activated in the last ca. 800 years.

\subsection{Interpretation of the trench data}

These fault traces weare clear in all of the trenches and field observations, and they obtained ages that suggest that Tecer Fault was activated at least twice during the last 10000 years. We defined an earthquake in Trench-1 after ca. 3500 B.C. Trench-2 provided two past earthquakes: the older one took place after ca. 8000 B.C., but we do not have an age for its upper limit in this trench. The trench data suggest that the more recent event occurred between ca. 3600 B.C. and 3400 B.C. Trench-1 and Trench-2 were only $50 \mathrm{~m}$ away from each other, and the age of the event in Trench-1 is in the range of the more recent event in Trench-2. Thus, the more recent event in Trench-2 is comparable with the data in Trench-1, and this comparison suggests that an earthquake occurred around 3500 B.C. Paleoseismological data from Trench-3 provided an upper limit for an earthquake as ca. 7700 B.C. This date is also comparable with the age of the older event in Trench-2. On the basis of these combined data from Trench2 and Trench-3, we can conclude that the older earthquake took place around or just after 8000 B.C. A wedge-shaped infill was exposed in Trench-4, and assuming that it is related with faulting, we can conclude that an event occurred before ca. 1200 A.D. However, there was not enough data to refer this earthquake to any event that was defined in the other trenches. As Figure 13 shows, interpretation of these paleoseismological data suggests that two surface-rupturing earthquakes have occurred on Tecer Fault in the last 10000 years.

\section{Discussion and conclusions}

Tecer Fault is a poorly known structure in central Anatolia. It is the eastward continuation of Deliler Fault, which was mapped as a probable active fault by Saroglu et al. [1992]. Although Tecer Fault has been mapped previously [e.g. Aktimur et al. 1990], to our knowledge, there has been no studies about its activity. Tecer Fault was mapped in detail during the present study. Our field observations and paleoseismological data clearly suggest that Tecer Fault is active. As the Deliler Fault is the western continuation of Tecer Fault, the NE-SW-trending Deliler Fault can also be considered as an 'active fault' instead of the 'probable active fault' of Saroglu et al. [1992].

Two surface-rupturing earthquakes were demonstrated for Tecer Fault in these trench studies. The older event might have occurred around or just after 8000 B.C. (Figure 13). The date limits are more constrained for the more recent event, and these give an earthquake for ca. 3500 B.C. According to the trench data, there have been no surface-rupturing earthquakes over last 800 years. These data clearly show that Tecer Fault and Deliler Fault are active structures, and that they have produced large earthquakes that have generated surface 


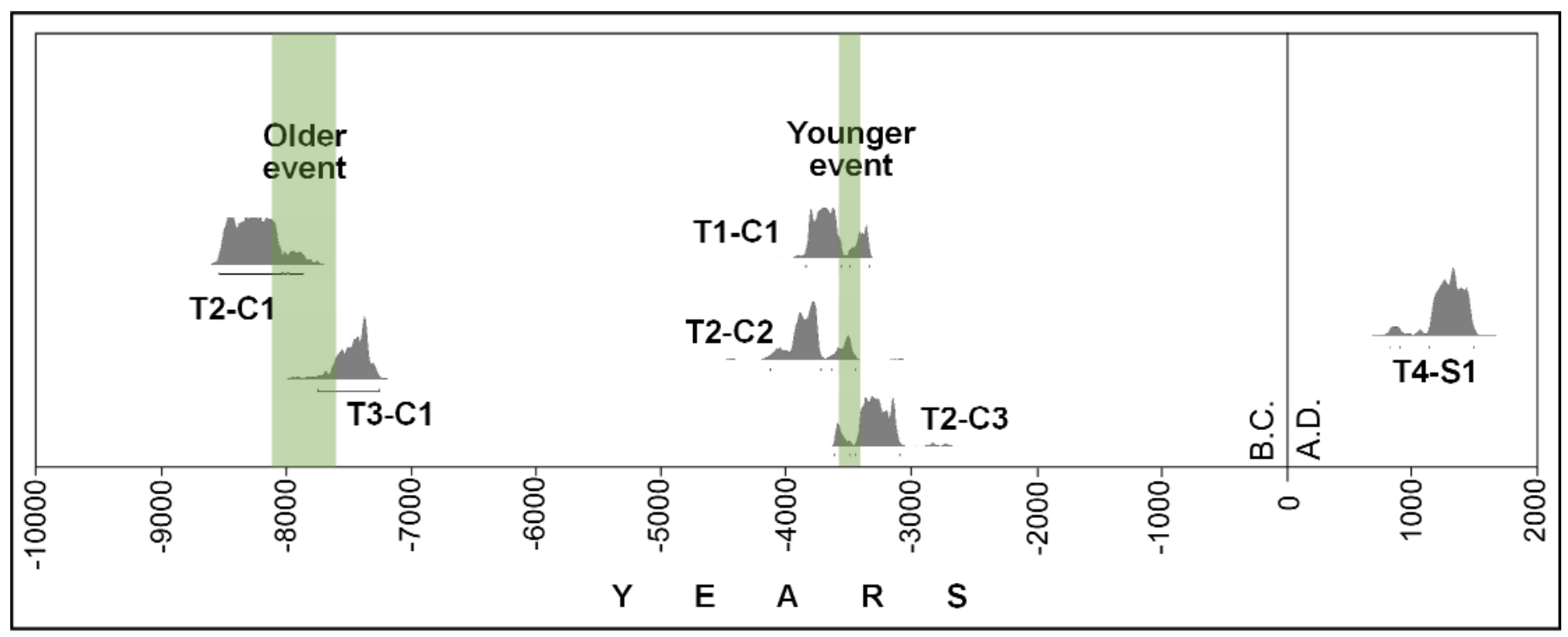

Figure 13. Probability distribution of calibrated ${ }^{14} \mathrm{C}$ ages obtained from sequential radiocarbon dates. Measurements were calibrated by $\mathrm{OxCal}$, version 4.1.7 [Bronk Ramsey 2009], in which the atmospheric correction curves were those of Reimer et al. [2009].

ruptures in the past, and that they will rupture in the future. Present data is limited for the calculation of a precise interval for the large earthquakes on Tecer Fault. Additional paleoseismological data from different parts of Tecer Fault, and more importantly from Deliler Fault, will provide important information relating to the Holocene (and older) activity and to the seismic risk assessment of the CAFZ.

This study indicates that Tecer Fault participated in the deformation of the Anatolian Block, together with Deliler Fault. Considering that the length of Tecer Fault is ca. $45 \mathrm{~km}$, the probable magnitude of an earthquake that ruptures Tecer Fault would be expected to be ca. 7.0-7.1 [Wells and Coppersmith 1994], which is also comparable with the November 12, 1999, Duzce earthquake (M 7.1) [Akyuz et al. 2002, Barka et al. 2002]. Due to lack of GPS data for this area, we do no have slip rates for Deliler Fault and Tecer Fault. However, taking into account the time span between these defined earthquakes, a slip rate of about $1 \mathrm{~mm} / \mathrm{yr}$ can be obtained for Tecer Fault, which is comparable with other strike-slip earthquakes in Turkey, in terms of the time-slip relationship.

\section{References}

Aktimur, H.T., M.E. Tekirli and M.E. Yurdakul (1990). SivasErzincan Tersiyer Havzasının Jeolojisi (Geology of SivasErzincan Tertiary Basin), MTA, 111, 25-36.

Akyuz, H.S., R. Hartleb, A.A. Barka, E. Altunel and G. Sunal (2002). Surface rupture and slip distribution of the November 12, 1999, Düzce Earthquake (M 7.1), North Anatolian Fault, Bolu, Turkey, Bull. Seismol. Soc. Am., 92, 61-66.

Ambraseys, N. (2010). Earthquakes in the Mediterranean and Middle East. A Multidisciplinary Study of Seismicity up to 1900, Cambridge University Press, 968 pp., ISBN 9780521872928.

Barka, A.A., H.S. Akyuz, E. Altunel, et al. (2002). The sur- face rupture and slip distribution of the August 17, 1999, zmit earthquake (M 7.4), North Anatolian Fault, Bull. Seismol. Soc. Am., 92, 43-60.

Bronk Ramsey, C. (2009). Bayesian analysis of radiocarbon ages, Radiocarbon, 51, 337-360.

Ergin, K, U. Guclu and Z. Uz (1967), Türkiye ve Civarının Deprem Katalogu (Milattan Önce 11 yılından 1964 sonuna kadar)/ A Catalog of Earthquakes for Turkey and the Surrounding Area (11 A.D. to 1964 A.D.), I.T.U. Mining Faculty Publ., n. 24.

Guidoboni, E., A. Comastri and G. Traina (1994). Catalogue of Ancient Earthquakes in the Mediterranean Area up to the 10th Century, vol. 1, INGV-SGA, Bologna 1994, 504 pp.

Guidoboni, E., and A. Comastri, (2005). Catalogue of Earthquakes and Tsunamis in the Mediterranean area from the 11 th to the 15 th Century, vol. 2, INGV-SGA, Bologna 2005, 1037 pp.

Gursoy, H., J.D.A. Piper, O. Tatar and H. Temiz (1997). A paleomagnetic study of the Sivas Basin, central Turkey: crustal deformation during lateral extrusion of the Anatolian Block, Tectonophysics, 271, 89-105.

Kalafat, D., K. Kekovali, K. Kilic, et al. (2008). An Earthquake Catalog for Turkey and the Surrounding Area $(M \geq 3.0$; 1900-2008), Kandilli Observatory and DAE, UDIM, Istanbul, (in Turkish).

Kocyigit, A., and A. Beyhan (1998). A new intracontinental transcurrent structure: the Central Anatolian Fault Zone, Turkey, Tectonophysics, 284, 317-336.

Kocyigit, A., and A. Beyhan (1999). Reply to Rob Westaway's Comment on 'A new intracontinental transcurrent structure: the Central Anatolian Fault Zone, Turkey', Tectonophysics, 314, 481-496.

McCalpin, J. (1996). Paleoseismology: Cambridge, Cambridge University Press, 588 pp. 
Reimer, P.J., M.G.L. Baillie, E. Bard, et al. (2009). IntCal09 and Marine09 radiocarbon age calibration curves, 0 50,000 years cal BP, Radiocarbon, 51, 1111-1150.

Saroglu, F., O. Emre and I. Kuscu (1992). Turkiye Aktif Fay Haritasi. (Active Fault Map of Turkey), M.T.A. Publication, Ankara, Turkey.

Sengör, A.M.C. (1980). Türkiye neotektoniginin esasları (Principles of the Neotectonics of Turkey), Turkiye Jeol. Kur. Public Conference series, Ankara, Turkey, n. 2, 40 pp.

Tan, O., M.C. Tapirdamaz and A. Yörük (2008). The Earthquake Catalogues for Turkey, Turkish J. Earth Sci., 17, 405-418.

Wells, D.L., and K.J. Coppersmith (1994). Empirical relationships among magnitude, rupture length, rupture area, and surface displacement, Bull. Seismol. Soc. Am., 84, 974-1002.

Westaway, R. (1999). Comment on "A new intracontinental transcurrent structure: the Central Anatolian Fault Zone, Turkey" by A. Kocyigit and A. Beyhan. Tectonophysics, 314, 469-479.

Westaway, R. (2003). Kinematics of the Middle East and Eastern Mediterranean updated, Turkish J. Earth Sci., 12, 546.

Yilmaz, A., M. Sumengen, I. Terlemez and T. Bilgic (1989). 1:100 000 Olcekli Acinsama Nitelikli Türkiye Jeoloji Haritalari Serisi, Sivas-G 23 Paftasi (1:100 000 scale exploratory Turkish geological map series, Sivas-G23 sheet), MTA Publ., Ankara, Turkey.

\footnotetext{
*Corresponding author: H. Serdar Akyuz, Istanbul Technical University, Faculty of Mines, Department of Geological Engineering, Istanbul, Turkey; email: akyuz@itu.edu.tr. 